\title{
Evaluation of Grapefruit Juice in terms of Interleukin 18 Gene Expression in Rats with Fatty Liver and Healthy Rats
}

\author{
Simin Bahman Poor ${ }^{1}$, Noosha Zia-Jahromi ${ }^{*}$ \\ ${ }^{1}$ Dept of Biology, Science Faculty, Falavarjan Branch, Islamic Azad University, Falavarjan, Iran \\ ${ }^{2}$ Dept of Biology, Science Faculty, Shahrekord Branch, Islamic Azad University, Shahrekord, Iran
}

Article Info A B S T R A C T

Article type:

Research article

\section{Article History:}

Received: 03 February 2021

Revised: 22 February 2021

Accepted: 21 June 2021

\section{* Correspondence to:}

Noshin Zia-Jahromi

Dept of Biology, Science Faculty, Shahrekord Branch, Islamic Azad

University, Shahrekord, Iran

Email: Nooshazia.59@gmail.com
Introduction: Interleukin 18 (IL-18) is a member of the cytokine family and an important regulator of inflammatory reactions. Due to the severe and irreversible complications of this disease in the advanced stages, timely treatment, especially with herbal medicines, can be considered an important strategy. This study aimed to investigate the effect of grapefruit extract on the IL-18 gene expression in mice with fatty liver.

Material \& Methods: In this study, 24 male Wistar rats weighing $180 \pm 20$ g were divided into four groups (positive control, negative control, first treatment, and second treatment). The two treatment groups received grapefruit extract 4 and 8 $\mathrm{ml} / \mathrm{kg}$ by gavage for 5 weeks, respectively. Finally, the rats were anesthetized with chloroform, and after dissection, the liver tissue and blood samples were collected. Subsequently, RNA extraction and cDNA synthesis were performed using the relevant kits according to the protocol, and finally the expression of IL18 gene was performed using Real-time polymerase chain reaction (RT-PCR) technique, and the relevant analyzes were performed.

(Ethic code: IR.IAU.SHK.REC.1399.049)

Findings: In the present study, the results showed that grapefruit extract at a dose of $8 \mathrm{ml} / \mathrm{kg}$ could further reduce the expression of IL-18 gene, compared to a dose of $4 \mathrm{ml} / \mathrm{kg}$ in rats with fatty liver. This decrease in the rate expression was significant in the patient group $(\mathrm{P}<0.05)$. The results of biochemical tests confirmed liver improvement in treated rats at a dose of $8 \mathrm{ml} / \mathrm{kg}$.

Discussion \& Conclusion: Grapefruit juice seems to reduce various symptoms of inflammation due to its orange content by reducing the expression of the IL-18 gene in rats with a fatty liver that can be considered a therapeutic target in fatty liver disease.

Keywords: Fatty liver, Grapefruit, Interleukin 18 gene, Real-time (RT)-PCR technique

\footnotetext{
How to cite this paper

Bahman Poor S, Zia-Jahromi N. Evaluation of Grapefruit Juice in terms of Interleukin 18 Gene Expression in Rats with Fatty Liver and Healthy Rats. Journal of Ilam University of Medical Sciences. November 2021;29(4): 74-82.
} 


\section{بررسى آب ميوه كريبفروت بر بيان زُن اينترلوكين Aا در رت هاى مبتلا به كبد جرب و

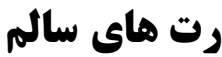

(iD)

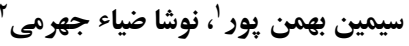

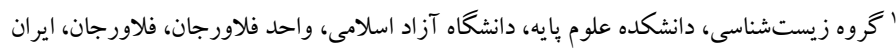

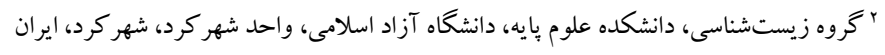

קكيده

مقدمه: IL18 عضوى از خانو ادهُ سايتو كاين است و تنظيم كنندة مهم واكنشهاى التهابى است. با توجه به عوارض شديد

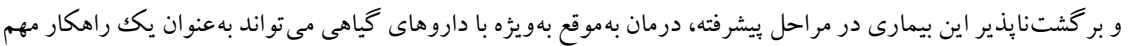

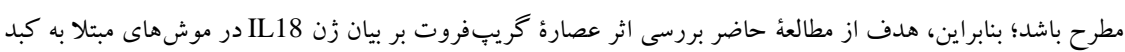$$
\text { خرب است. }
$$

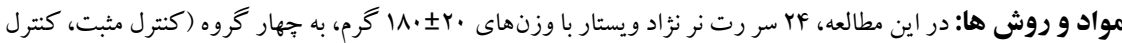

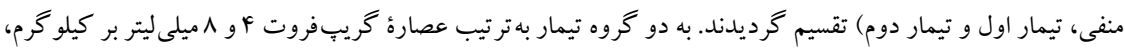

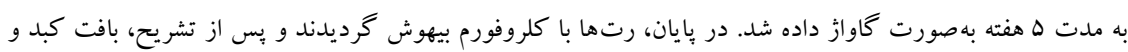

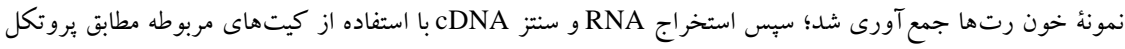

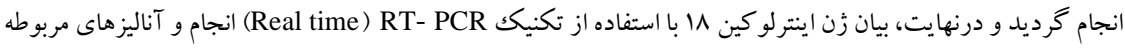
صورت كرفت

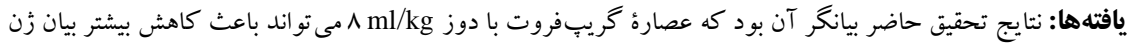
نسبت به دوز IL18

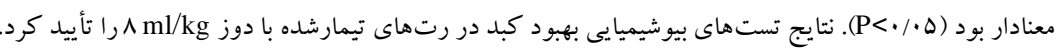

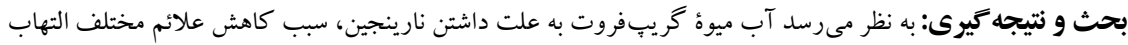

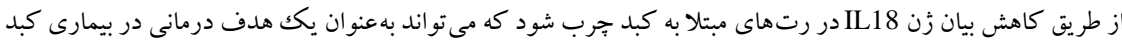
جرب مطرح باشد.
تاريخ دريافت: 1/11/ تاريخ داورى: 1/12/09/1

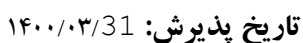

$$
\text { نويسنده مسئول: }
$$

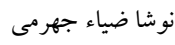
كروه زيستشناسى، دانشكده علوم

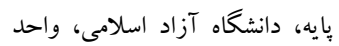

$$
\text { شهر كرد، شهر كرد، ايران }
$$

Email:

Nooshazia.59@gmail.com

وازههاى كليدى: گريبفروت، زن اينترلو كين 11، كبد جرب، تكنيك Real time) RT- PCR

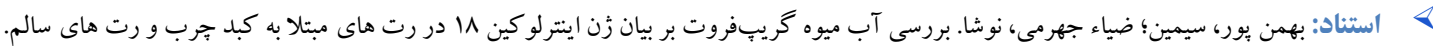

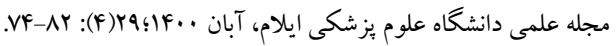


گَاه مطالعهده در تحقيق حاضر گريبِفروت است

كu گياهى از تيرهٔ مر كبات و در دستهٔ خانوادة Rutaceae

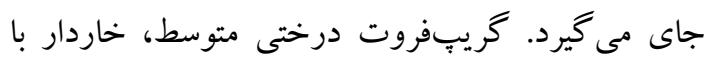

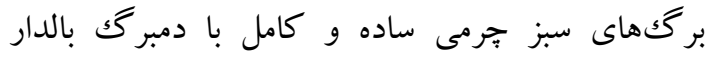

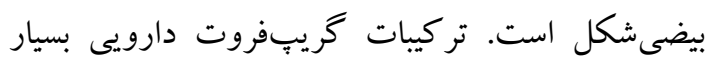
مؤثر و شفابخش براى قلب است (9) و همجنين سبب

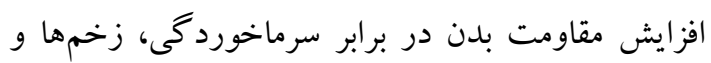
كاهش كلسترول مىشود و بهواسطةُ تأخير در تخلية معده، باعث كاهش خربى بدن مى گردد (.1). آب ميوه

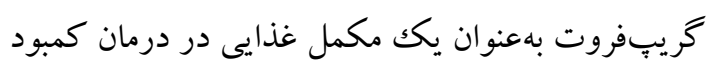

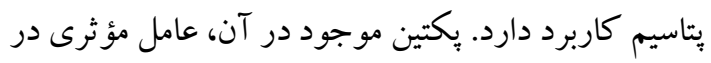
كاهش كلسترول خون و بهبود تدريجى عارضئ سفتوسخت شدن عروق خونى است. ساير آثار آن شامل

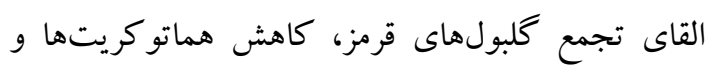
اثرات احتمالى ضدسرطان است (11).

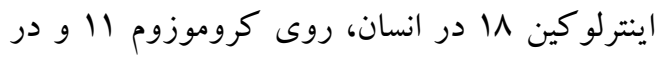

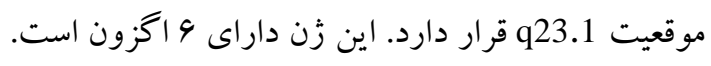
اينترلو كين 11 عضوى از خانو ادهُ سايتو كاين اينترلو كين

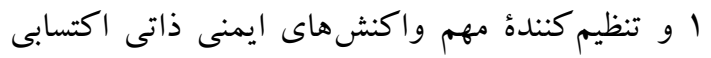
است و در بى ثباتى پِلاكت ها نقش دارد. ارتباط سطوح

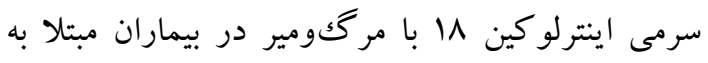
بيمارى سرخركى كرونرى و عوارض كرونرى مردان

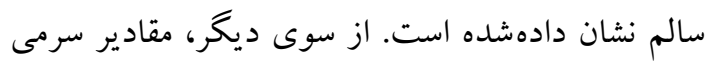
اينترلوكين 11 با مقاومت انسولينى ارتباط دارد.

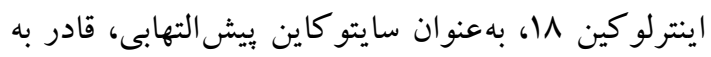

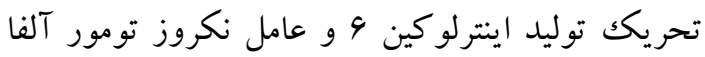

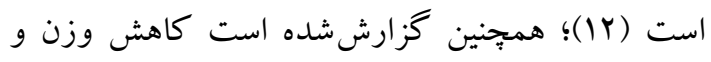
سندرم متابوليكى با اينترلو كين 1 همبستخى دارد و ونيز

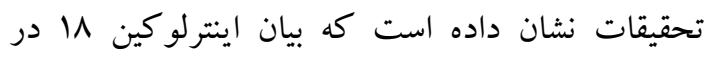
بيمارىهاى عفونى و در بعضى از بيمارىهاى مزمن

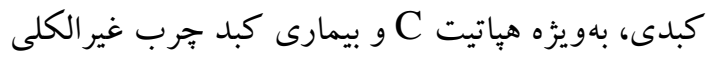

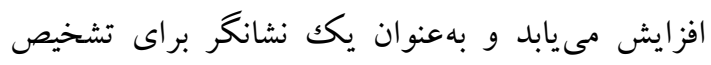
بيمارىهاى كبدى بسيار اهميت دارد (با).
بيمارى كبد جرب غير الكلى هنگامى ظهور مى كند كه

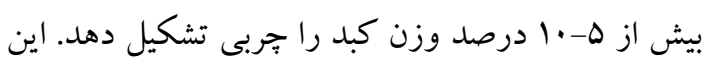

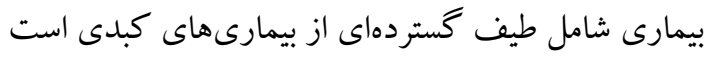

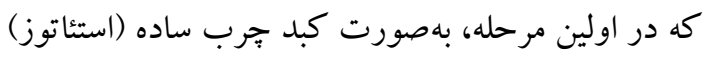

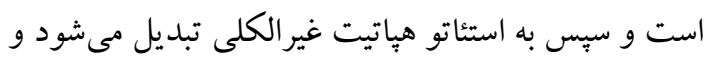
درنهايت، به سيروز كبدى منجر مى گردد (1). اصلى ترين

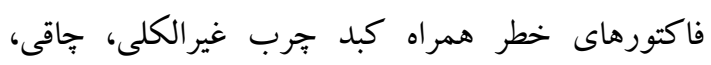
ديابت، هييرليييدمى و سندروم متابوليك است. در حقيقت،

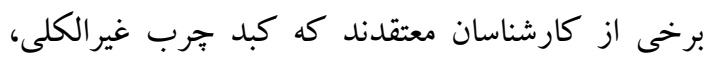
تظاهر كبدى مقاومت به انسولين يا سندروم متابوليك كارئ

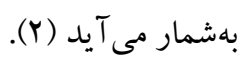
افزايش شاخصهاى التهابى C-reactive-) hs-CRP

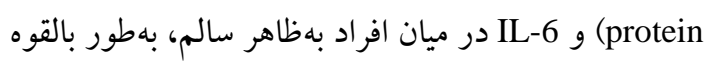
با افزايش خطر بيمارىهاى قلبى -عروقى همراه است،

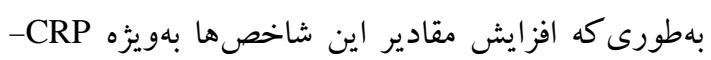
Chs

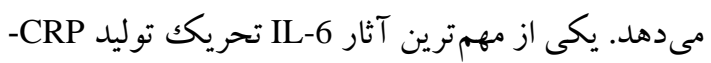

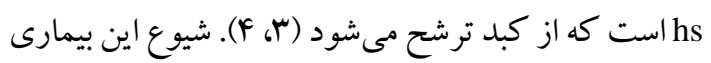

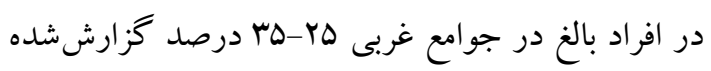

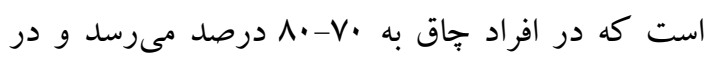
جوامع آسيايى حدود 19-هاه درصد است (ه). در ايران،

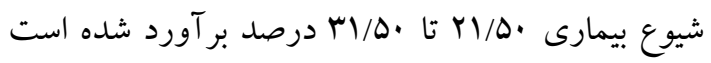

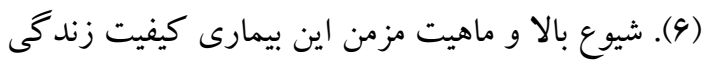

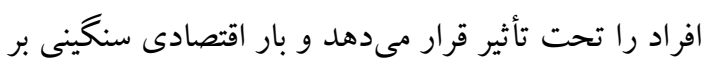
جامعه تحميل مى كند. سودمندى و ايمنى درمان دارويى كبد جرب تاكنون نامعلوم باقىمانده است (V)

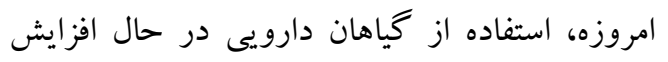
است و به علت عوارض جانبى داروهاى شيميايى، مردم ترجيح مىدهند از داروهاى گياهى استفاده كنداء

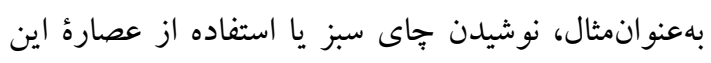

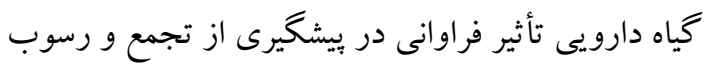
جربىها در اطراف كبد مىشود، ضمن آنكه مىتواند به ديه

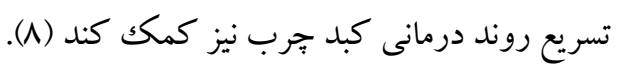


و رطوبت محل نغهارى، آزمايشها آغاز شد. در ضمن، اصول اخلاقى كار با حيوانات آزمايشگاهى در همؤ مراحل لحاظ گرديد.

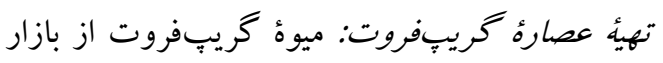

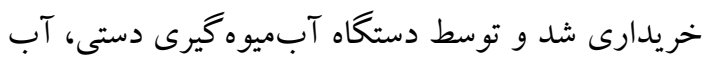

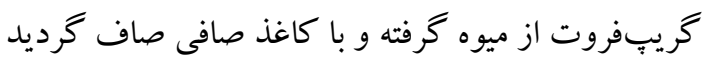

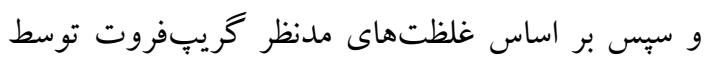
آب مقطر رقيقسازى صورت گرفت.

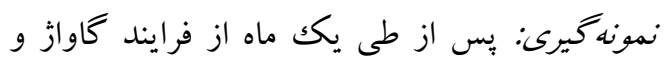
تيمار، رتها در شرايط كاملاً بهداشتى، با استفاده از باز كلروفورم بيهوش و با استفاده از ست جر احى، شكم آنها باز و كبدشان برداشته شد؛ سيس مقدارى از كبد براى انجام مراحل ريل تايم درون RNA later قرار داده و در فريزر

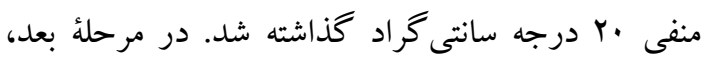

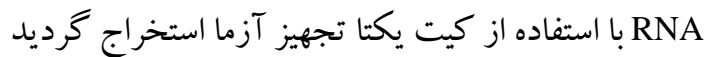
و درنهايت، بررسى كمى و كيفى آن با استفاده از دستگًاه

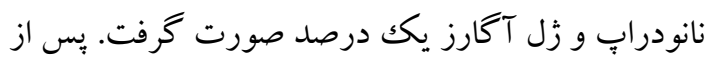
اطمينان از خلوص RNA استخراجشده، با استفاده از كيت r. يكتا تجهيز آزما cDNA ساخته شد و به فريزر منفى بعل منقل گرديد. در ادامه براى بررسى زن موردمطالعه،

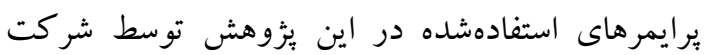
Primer 3D سينارن، بر اساس توالى زن كه توسط نرمافزار

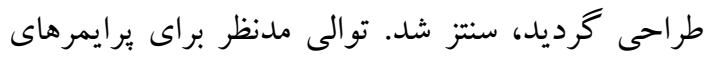
استفادهده در جدول شماره آ آمده است.

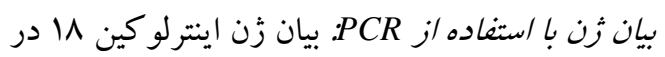

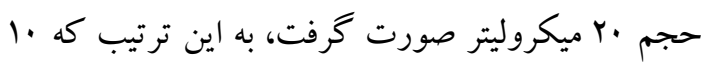

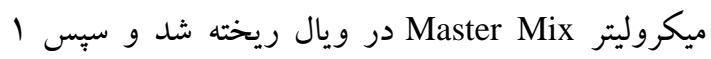

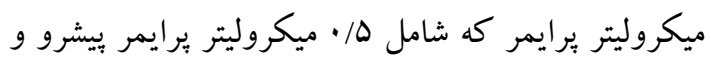

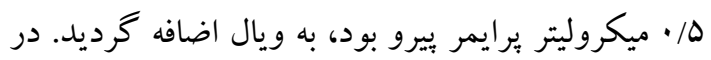
ادامه، ا ميكروليتر از cDNA ساختهشده به ويال افزوده

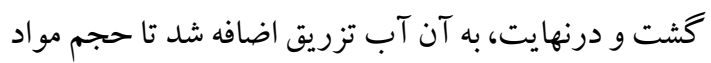

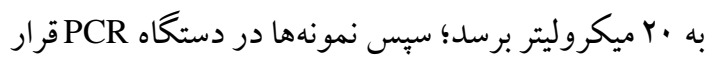
كرفت و دستكاه طبق برنامُٔ مدنظر تنظيم گرديد كه شامل AF Initial denaturation step
با توجه به اينكه اينترلوكين M يك سايتو كاين

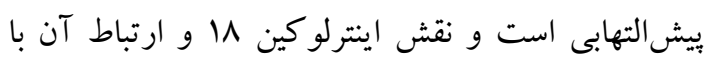

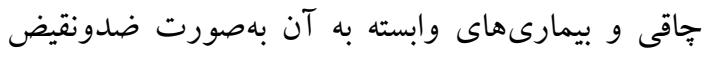

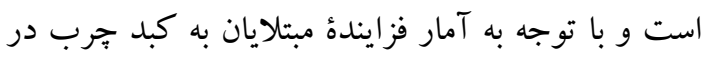

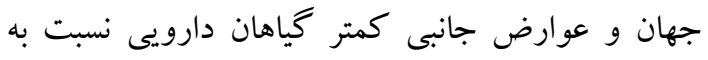
داروهاى صنعتى و شيميايى، در اين مطالعه، اثر عصارة

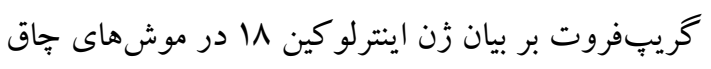
مبتلا به كبد جرب بروسى شده است.

\section{مواد و روش ها}

نوع مطالعه، جامعه آمارى و گرووبندى: مطالعئ حاضر يُزوهشى تجربى بود كه در كميتة اخلاق دانشگاه آزاد

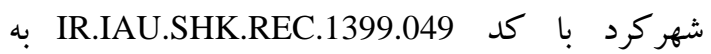
تصويب رسيده است. روش گردآورى اطلاعات بهصورت

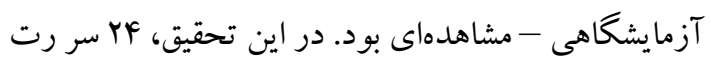

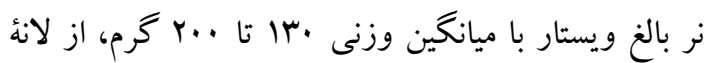

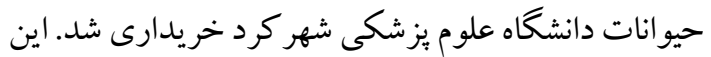

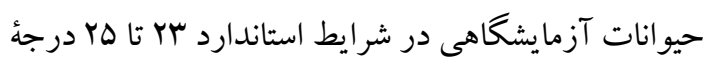

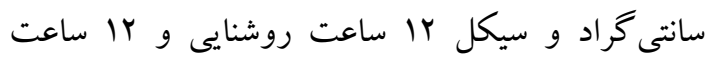
تاريكى، با آب و غذاى كافى و استاندارد، درون قفسهاى مخصوص دانشگاه آزاد اسلامى واحد شهر كرد نخههدارى گر ديدند. رتها بِ از ساز گارى با محيط، بهطور تصادفى

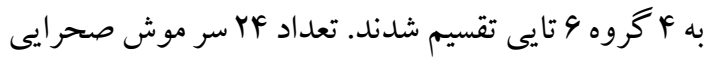
بهصورت تصادفى، به F كروه آزمايشى تقسيم گرديدند: كروه A شامل شش سر رت سالم كه روزانه تنها آب و غذاى استاندارد دريافت مى كنند و گروه كنترل را تشكيل

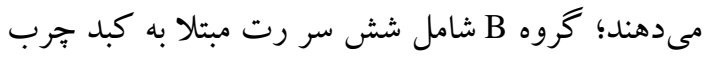
است كه بهعنوان گروه كنترل منفى در نظر گرفته شدند؛

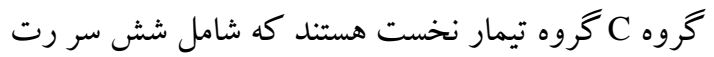
مبتلا به كبد جرب است كه دريافت كنندة دوز

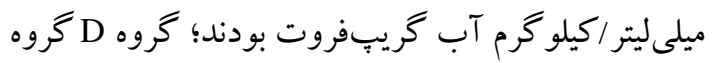

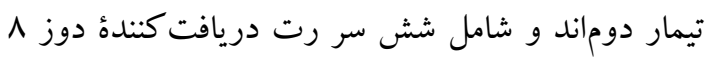

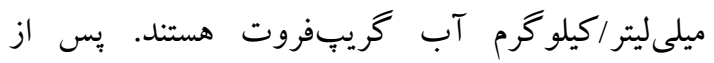
كروهبندى و از طى شدن دورهُ تطبيق حيوانات با حرارت 
جدول ا. برايمرهاى استفادهشده در اين تحقيق

\begin{tabular}{|c|c|c|c|}
\hline 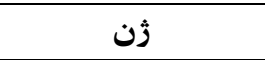 & 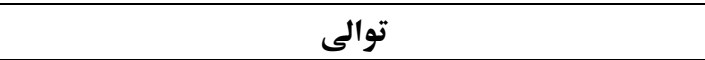 & دما & 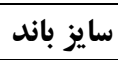 \\
\hline Interleukin-18- F & '5'- GACAACACAC TTTACCTTATACCTG -3 & \multirow{2}{*}{$\mathrm{C}^{\circ} 59$} & \multirow{2}{*}{$119 \mathrm{bp}$} \\
\hline Interleukin-18- R & '5'- ACGAAGAGAACTT GGTCATTTATG -3 & & \\
\hline $\begin{array}{l}G A P D H-F \\
G A P D H-R\end{array}$ & $\begin{array}{l}\text { '5'- TGATTCTACCCA CGGCAAGTTC-3 } \\
\text { 'CGCTCCTGGAA GATGGTGATG-3-5' }\end{array}$ & $\mathrm{C}^{\circ} 56$ & $r \cdot \mathrm{bp}$ \\
\hline
\end{tabular}

كرديد و نتيجهُ بهدست آمده ارزيابى شد.

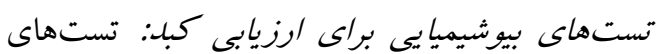

بيوشيميايى شامل تست كلسترول، ترى گليسريد، قند،

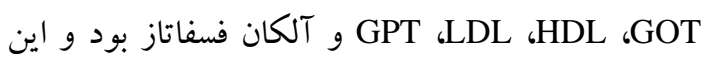
آزمايشها با روش اتوآناليزر و توسط دستخاه اتو آناليزر (BT 3000plus Analyser Auto)

$$
\text { صورت كرفت. }
$$

روش تجزيهوتحليل دادهها: در اين بررسى، براى آناليز آمارى دادهها از نرمافزار SPSS vol.22 استفاده شد.

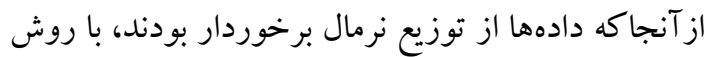
آناليز واريانس يككرفه (ANOVA) و با آزمون بشتيبان

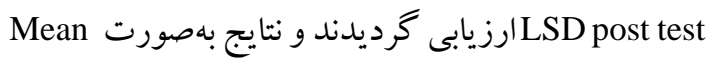
P>0.05 I SEM

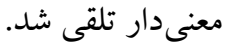

درجة سانتى گراد، Denaturation به مدت •r ثانيه و

در دماى Af درجة سانتى گراد، Annealing به مدت .ب

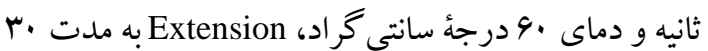

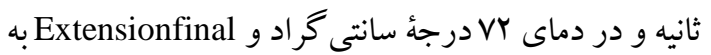

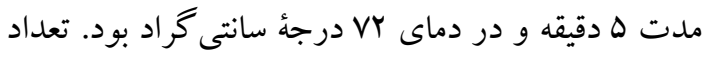

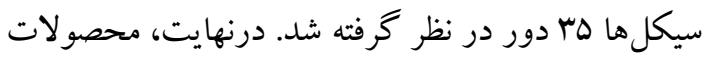

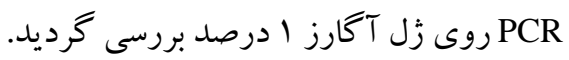
تكنيك RT-Real Time PCR براى انجام تكنيك ريلتايم بر اساس يروتكل كيت يكتا تجهيز آزما، ل1

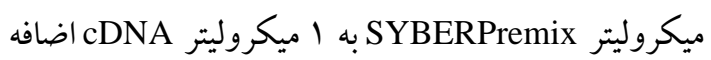
شد و سبس از هر كدام از ير ايمرهاى بيشرو و ييرو، به مقدار

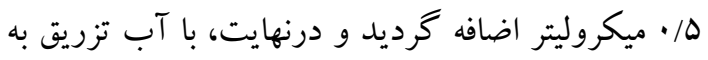

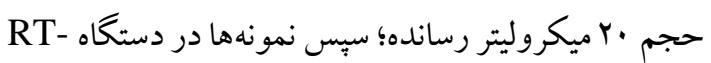

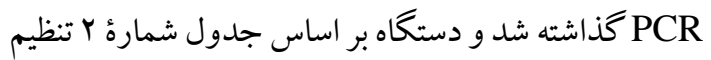

جدول rا. مقايسٔ ميزان تغييرات بيان زن IL18 در گروههاى مختلف

\begin{tabular}{|c|c|c|c|c|}
\hline 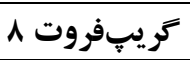 & كريڤضروت ع & بيمار & سالم & كروه \\
\hline $1 / 19 \pm \cdot / / 1^{b}$ & $1 / \wedge a \pm 1 / r q^{b}$ & $r / \Delta \cdot \pm \cdot / \Delta V^{a}$ & $1 / \cdot r \pm \cdot / r r^{b}$ & بيان اينترلو كين 1风 \\
\hline
\end{tabular}

واكنش PCR انجام شد. پِ از الكتروفورز محصولات

يافته ها

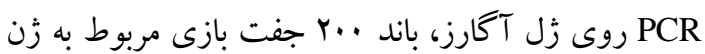
بررسى كيفى RNA/ستخراجشله: براى كسب اطمينان مشاهده گرديد كه تأيد سنتز مناسب CDNA بود. از تجزيه نشدن RNA استخراجشده، نمونههايى كه در در شكل شمارةٔ انتايج آن نشان دادهده است. شرايط free RNase تهيهشده بودند، روى زل آكارز يك

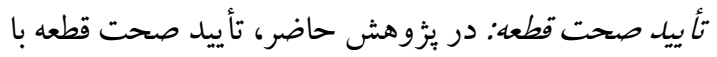
RNA درصد بررسى گرديدند. ازآنجاكه بيشترين ميزان

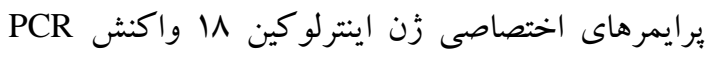

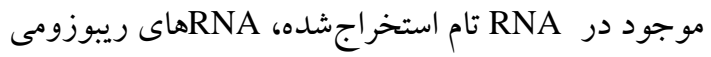

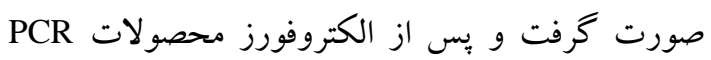
روى زل آكارز يك درصد، باند 119 اجنت بازى مشاهده

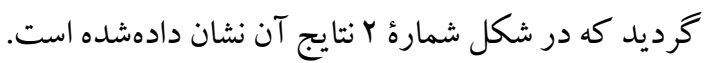

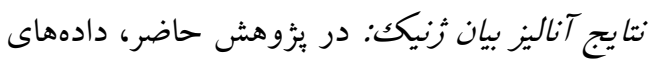

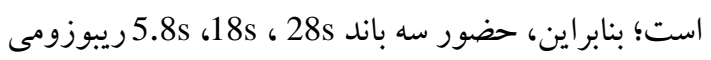
نشاندهندة كيفيت استخراج RNA نهاى مدنظر بود.

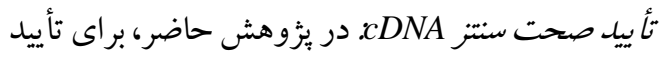
صحت سنتز cDNA با يرايمرهاى اختصاصى زن GAPDH، 

استفاده از آزمون آمارى T-test independent و سطح در رتهاى دوز ^ اين كاهش بيان جشمخير و معنادار بود معنىدارى ه•/P صورت گرفت و بررسى دادههاى بهدست آمده از بيان زن اينترلوكين 11 نشان داد كه آب نتايج تستهاى بيوشيميايى: همانطور كه در شكل كريبٍفروت سبب كاهش بيان زن اينترلو كين 11 مي شود شماره F F مشاهده مىشود، نتايج تستهاى بيوشيميايى، و اين كاهش بيان از نظر آمارى معنادار بود (ه •/P> (P). در ب بهبود كبد در رتهاى تيمارشده با دوز جدول شمارة Y بررسى بيان زن اينترلوكين \1 نشان ميلىليتر /كيلو كرم گريبٍفروت را تأييد مى كند. دادهشده است.بر اساس جدول شماره Y بيشترين ميز ان بيان مربوط به كروه رتهاى مبتلابه كبد جرب و كمترين ميزان

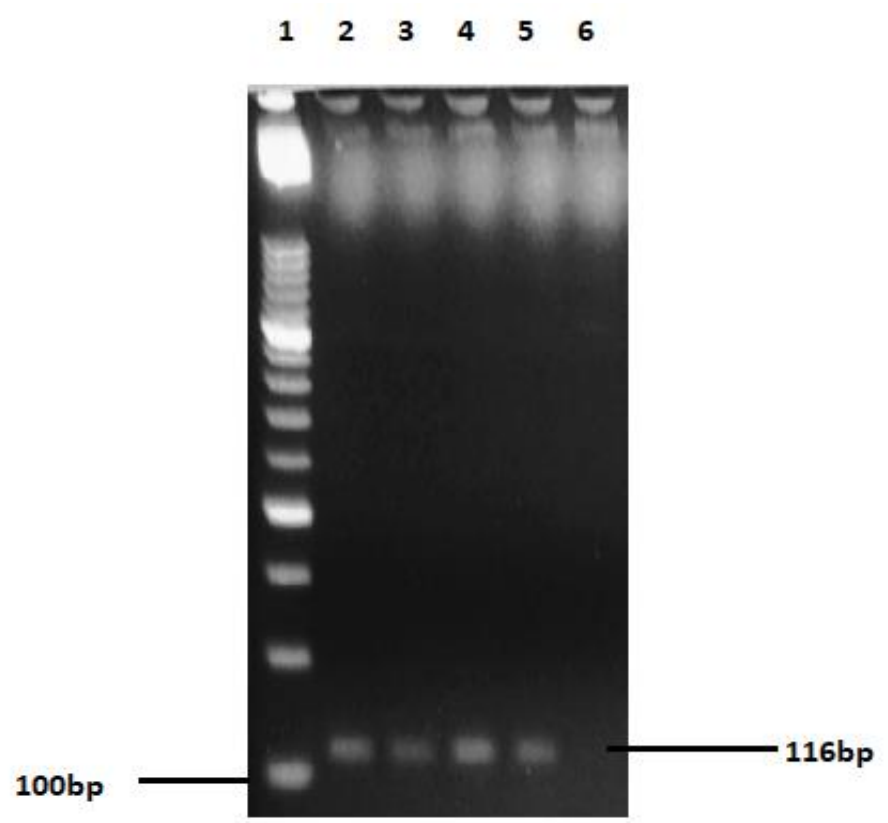

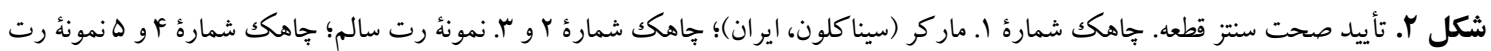
بيمار؛ جاهك شمارة: 9. كنترل منفى 


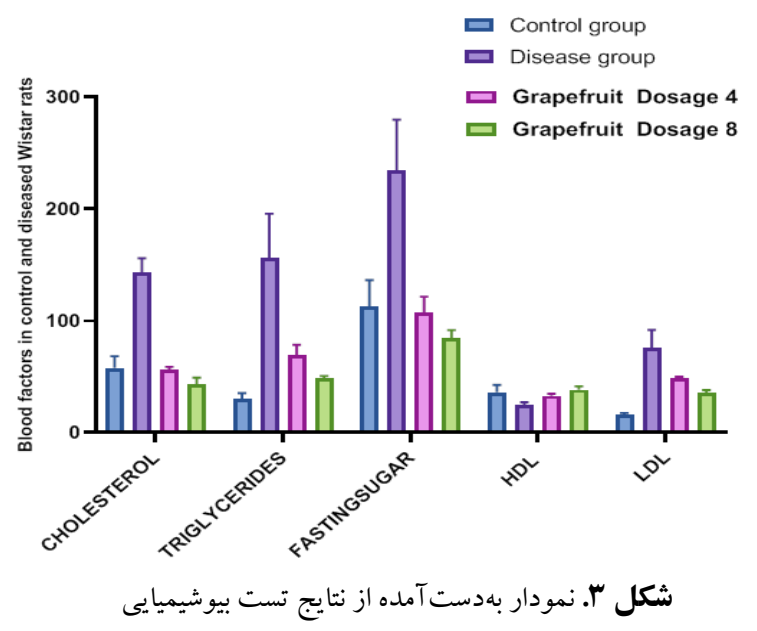

تحقيق حاضر نيز نتايج بيانكر آن بود كه عصارة ميوه

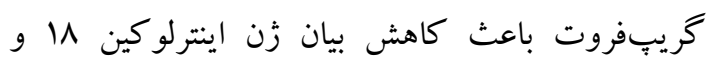
درنتيجه، كاهش التهاب مى گردد.

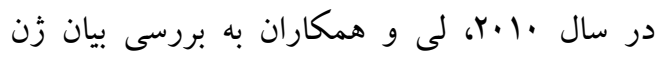

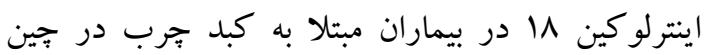

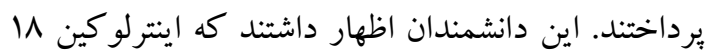
متعلق به سايتو كاينهاى ضدالتهابى است و مطالعات بيشين

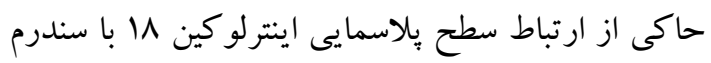

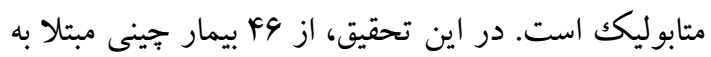

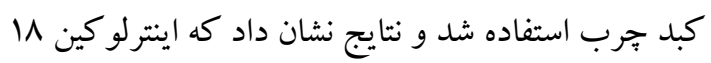

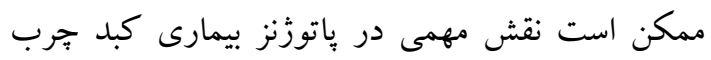

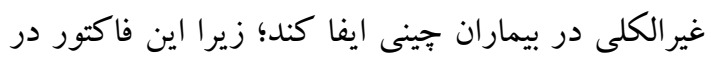

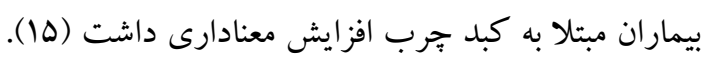
نتايج تحقيق حاضر بيانگر آن بود كه عصارة ميوه كريبِفروت باعث كاهش بيان زن اينترلو كين ل1 امىشود

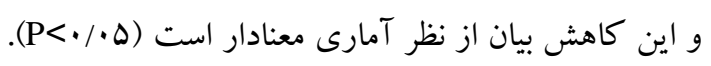

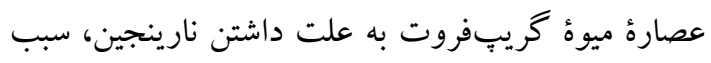
كاهش علائم مختلف التهاب نظير اينترلوكين 1 ا در

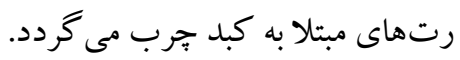

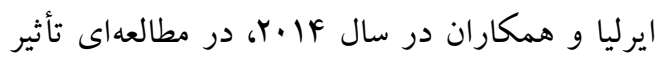
مصرف آب گريبٍفروت بر بهبود مقاومت به انسولين

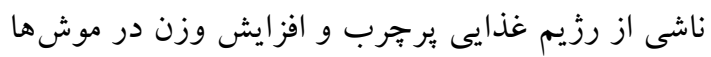

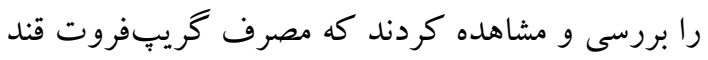
خون را كاهش مىدهد و تحمل انسولين را بهبود

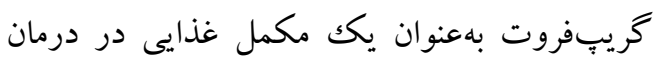
كمبود بِتاسيم كاربرد دارد. يُكتين موجود در آن، عامل مؤثرى در كاهش كلسترول خون و بهبود تدريجى عارضة سفتوسخت شدن عروق خونى است (11). در تحقيق حاضر، عصارة ميوه گريبفروت بر بيان زن اينترلو كين 11

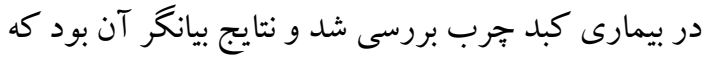

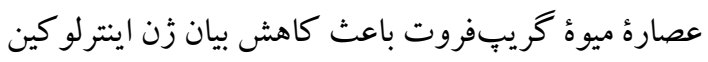
11 مىشود و اين كاهش بيان از نظر آمارى معنادار است

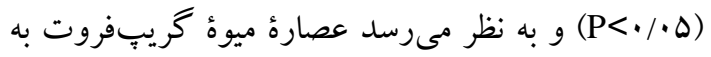
علت داشتن نارينجين، سبب كاهش علائم مختلف التهاب

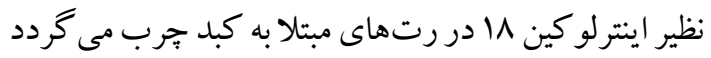
كه در صورت تأييد در مطالعات وسيع تر مى تواند بهعنوان

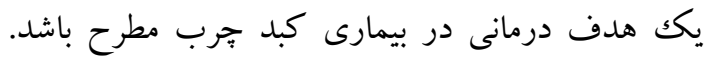

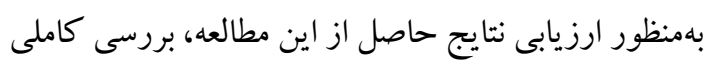

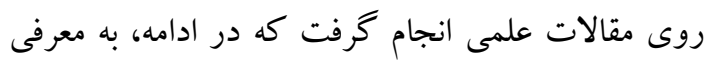

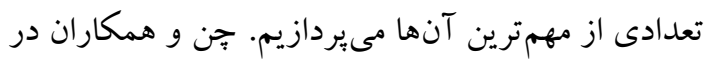

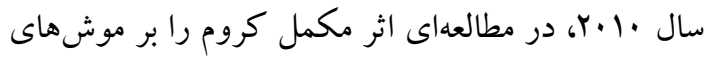
مبتلا به كبد جرب غير الكلى بررسى كردند و مشاهده

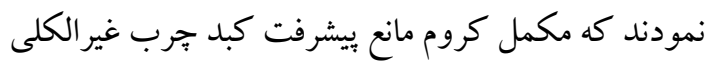

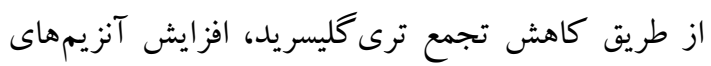

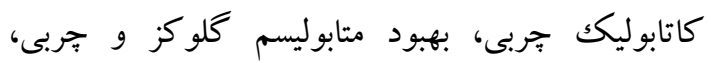
سركوب التهاب و كاهش استرس اكسيداتيو مىشود كه

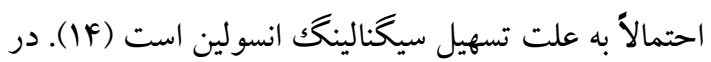


مصرف روزانهُ اين ميوه را در كاهش علائم مؤثر مىدانند.

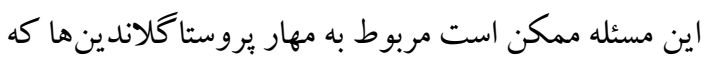
تركيبات التهابزا هستند، توسط تركيبات آن باشد و با توجه به نتايج تحقيق حاضر كه بيانكر آن بود عصاره آب

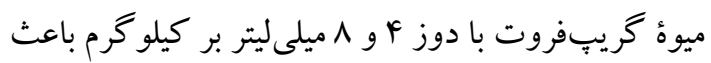
كاهش بيان زن اينترلوكين 11 مىشود، به نظر مىرسد عصارة ميوه گريبٍ فروت به علت داشتن نارينجين، سبب

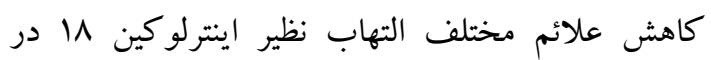
رتهاى مبتلا به كبد جرب مىشود كه نتايج تستهاى بيوشيميايى، بهبود كبد در رتهاى تيمارشده با دوز ميلى كرم/كيلو گرم را تأييد كرد و در صورت تأييد در مطالعات وسيع تر مىتواند بهعنوان يكك هدف درمانى در

$$
\text { بيمارى كبد جرب مطرح باشد. }
$$

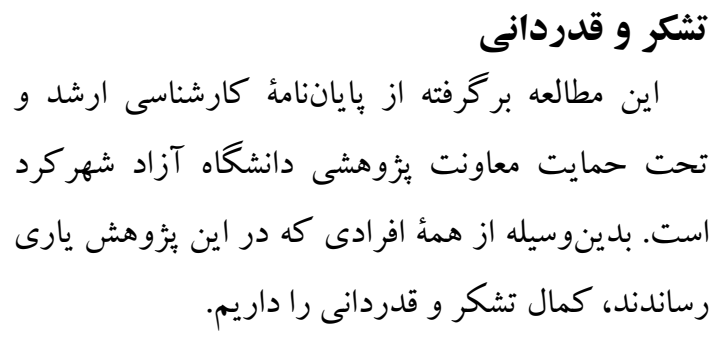

تعارض منافع مطالعه وجود ندارد. اعلام مى كنند كه تضاد منافعى در اين

كد اخلاق:

\section{References}

1. Lee BW, Lee YH, Park CY, Rhee EJ, Lee WY, $\mathrm{Kim} \mathrm{NH}$, et al. Non-alcoholic fatty liver disease in patients with type 2 diabetes mellitus a position statement of the fatty liver research group of the korean diabetes association. Diabetes MetabJ2020; 44:382-401. doi. 10.4093/dmj.2020.0010

2. Nolan CJ, Prentki M. Insulin resistance and insulin hypersecretion in the metabolic syndrome and type 2 diabetes time for a conceptual framework shift. Diabete Vascul Dis Res2019; 16:118-27. doi.10.1177/1479164119827611

3. Avan A, Tavakoly Sany SB, Ghayourmobarhan M, Rahimi HR, Tajfard M, Ferns G. Serum C-reactive protein in the prediction of cardiovascular diseases overview of the latest clinical studies and public health practice. J Cell Physiol2018; 233:8508-25.
مىبخشد؛ اما در افزايش وزن تأثيرى ندارد؛ همجينين

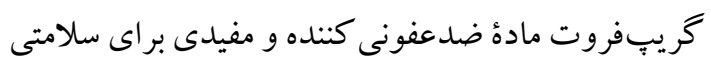

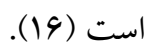

لون و همكاران اظهار داشتند كه آب ميوه كريبٍ فروت بهعنوان يكك مكمل غذايى در درمان كمبود يتاسيم كاربرد دارد. بـكتين موجود در آن، عامل مؤثرى در كاهش كلسترول خون و بهبود تدريجى عارضئ سفتوسخت شدن عروق خونى است (IV). در سال ها ب.r، حبييان و همكاران به تأثير تمرين مقاومتى دايرهاى و مكمل يونجه بر سطوح اينترلو كين 11 و ا در دختران جوان با شاخص تودهُ بلنى يايين يرداختند. طبق نتايج اين مطالعه، مداخله تمرين مقاومتى همر اه با مكمل يونجه ممكن است بهعنوان يكك راهكار مهم غيردارويى، وضعيت ضدالتهابى را در افراد با شاخص ئ لئ تودهُ بلدنى يايين بهبود بخشد (1N). نتايج يزوهش حاضر روى موشهاى جاق نشان داد كه آب ميوهُ گريبٍ فروت مىتواند باعث لاغرى در رتهاى جاق شود و به نظر

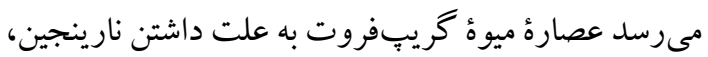
سبب كاهش علائم مختلف التهاب نظير اينترلو كين 11 در رتهاى مبتلا به كبد جرب مى گردد كه در صورت تأييد در مطالعات وسيعتر مىتواند بهعنوان يك هدف درمانى در بيمارى كبد خرب مطرح باشد.

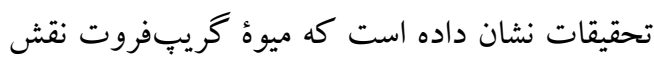
مهمى در كاهش التهاب دارد و برخى از بيماران مبتلا به آرتريت روماتوئيد، لويوس و ساير بيمارىهاى التهابى،

doi.10.1002/jcp.26791

4. Kato K, Otsuka T, Saiki Y, Kobayashi N, Nakamura T, Kon Y, et al. Elevated c-reactive protein levels independently predict the development of prediabetes markers in subjects with normal glucose regulation. Exp Clin Endocrinol Diabete2019; 23:1-25. doi.10.1055/a0869-7584

5. Williams CD, Stengel J, Asike MI, Torres DM, Shaw J, Contreras $M$, et al. Prevalence of nonalcoholic fatty liver disease and nonalcoholic steatohepatitis among a largely middle aged population utilizing ultrasound and liver biopsy a prospective study. Gastroenterology 2011; 140:124-31. doi.10.1053/j.gastro.2010.09.038

6. Lankarani KB, Ghaffarpasand F, Mahmoodi M, 
Lotfi M, Zamiri N, Heydari ST, et al. Nonalcoholic fatty liver disease in southern Iran a population based study. Hepat Monthl 2013; 13:32-7. doi.10.5812/hepatmon.9248

7. Godos J, Federico A, Dallio M, Scazzina F. Mediterranean diet and nonalcoholic fatty liver disease: Molecular mechanisms of protection. Int J Food Sci Nut2017; 68:18-27. doi. 10.1080/09637486.2016.1214239

8. Hsu S. Modified green tea polyphenols and methods thereof for treating liver disease. Patents2015;1-20. doi.10/US20150056194A1/en

9. Razavi BM, Hosseinzadeh H. A Review of the effects of citrus paradisi and Its flavonoids, naringin, and naringenin in metabolic syndrome. Bio Food Dietar Int Diabet2019:515-43. doi.10.1016/B978-0-12-813822-9.00034-5

10. Seleim M, Hassan MA, Saleh A. Physico chemical evaluation of white and pink grapefruit Citrus paradisi juice. Assi J Agri Sci 2019; 50:112-22. doi. 10.21608/ajas.2019.52742

11. Wang W, Wu X, Chantapakul T, Wang D, Zhang $\mathrm{S}$, Ma X, et al. Acoustic cavitation assisted extraction of pectin from waste grapefruit peels a green two stage approach and its general mechanism. Food Res Int 2017; 102:101-10. doi.10.1016/j.foodres.2017.09.087

12. Zhang NP, Liu XJ, Xie L, Shen XZ, Wu $J$. Impaired mitophagy triggers NLRP3 inflammasome activation during the progression from nonalcoholic fatty liver to nonalcoholic steatohepatitis. Lab Inv 2019; 99:749-63. doi.10.1038/s41374-018-0177-6

13. Elmahdy MK, Helal MG, Ebrahim TM. Potential anti-inflammatory effect of dapagliflozin in HCHF diet induced fatty liver degeneration through inhibition of TNF $\alpha$ and IL1 $\beta$ and interleukin 18 in Rat liver. Int Immunopharmacol 2020; 86:106730. doi.10.1016/j.intimp.2020.106730

14. Chen WY, Chen CJ, Liu CH, Mao FC. Chromium attenuates high fat diet induced nonalcoholic fatty liver disease in Mice. Biochem Biophys Res Commun2010; 397:459-64. doi.10.1016/j.bbrc. 2010.05.129

15. Li Y, Li Li Z, Qin L, Ying W. Plasma interleukin 18 binding protein ratio in Chinese with NAFLD. Hepatogastroenterology2010; 57:103-6. doi.10/article/med/20422882

16. Chudnovskiy R, Thompson A, Tharp K, Hellerstein M, Napoli JL, Stahl A. Consumption of clarified grapefruit juice ameliorates high fat diet induced insulin resistance and weight gain in Mice. PLos One 2014; 9:108408. doi.10.1371/journal.pone.0108408

17. Lown KS, Bailey DG, Fontana RJ, Janardan SK, Adair $\mathrm{CH}$, Fortlage LA, et al. Grapefruit juice increases felodipine oral availability in humans by decreasing intestinal CYP3A protein expression. J Clin Inv 1997; 99:2545-53.

18. Habibian M, Farzanegi P, Khakpour M. [The effect of circuit resistance training and medicago sativa supplement on interlukin 18 and interlukin 10 in young girls with low body mass index]. Qom Uni Med Sci J2015; 9:60-8. (Persian). 